\title{
Social and Structural Changes in Hungarian Talent Care: The case of a sports club
}

\author{
Velenczei Attila, Kovács Árpád, Szabó Tamás
}

Nemzeti Utánpótlás-nevelési és Sportszolgáltató Intézet Utánpótlás-nevelési Igazgatóság

ABSTRACT

Sociology of sport lacks information on the proper demographic description of athletes who are selected into a national sport talent care program. Therefore, the current study attempted to fill the gap in this area. Research from abroad has demonstrated that whilst sport appears to be a democratic social environment, the initial opportunities are not exactly equal. The majority of elite athletes come from the upper-middle class rather than the lower social classes (Coakley 1997, Eitzen \& Sage 1997). The objective of the current study was to identify the social status of young athletes, from the Central School of Sports in Budapest, who took part in a Hungarian government-sponsored national sports talent care program. Another objective of the study was to assess possible changes on the social ladder with time. We were able to address the second issue through the examination of data collected 30 years ago in the same milieu and to compare it - with certain precautions - with a similar dataset obtained in the course of the current work. The interpretation of the data was based on the statistical analysis of the examined periods. The main findings indicate that most athletes in the Central School of Sports come from an upper-middle class social background, but there were some differences in the various types of sport. For example, pentathletes and water polo players come from the most advantaged social class. It appears then, that membership in a given social class is more important than the fair skill-based selection process.

talent-care system, social background, sport-clubs, professional sport

\section{Introduction}

It is a demonstrated fact that sport works as a special sociological subsystem, and many researchers have examined the processes in this subsystem. Before the 1989-1990 political transition, in Hungary the sport system, similarly to the other subsystems, was under tight control, the sportsphere was directed by the central political and economic strata. The transition has not been completed in the sport-subsystem yet; the transformation has been considerably delayed.

It is not an over-exaggeration to state that Hungarian elite sport is in the world-elite; at all the modern Olympic Games, Hungarians finished in the top third of the participant countries. Hungarian sport can be considered as strongly Olympic-centred; popular expectations before major competitions can be regarded as significant, although the most recent research results have shown that this expectation has lowered to some extent. If we examine the state support of Olympic and non-Olympic 
sports, there is a considerable shift of balance to the Olympic ones; the majority of the annual state contributions are given to these associations. In exchange for this, the social demand is that the athletes perform well in competitions, sometimes above their potential, and that they win them.

The objective of this paper is to reveal what kind of radical changes can be identified in the social background of the young generation possessing a talent for sport. However, in order to provide an appropriate background, before the social background of the athletes is discussed, the following passages will describe the changing structural environment of sport-talent care training in Hungary in the past three decades.

\section{The structural context of Hungarian talent-care}

Until the 1920s, the manifestation of fundamental physical ability was enough for successful results (Harsanyi 2000). The development of the results and the changing role of sport led to the systematic establishment of talent-care systems, especially in the great sport-powers (with the GDR at the front of the list). At that time, the idea began to spread that seeking and managing the sporttalented youth should be an important area of science. The increasing significance of sporting achievement, the spread of the Olympic Spirit, the propagation of professionalism in sport led to an increasing number of athletes in the different international competitions. Sport became inspired by the expectations about the results, "simple talent" was not enough any more, and only those talented young athletes reached the top level who benefited from the optimal and suitable training-load. The successful participation in the international competitions was very important in a lot of countries (we have to emphasise the socialist states), and these countries developed unique talent-care systems.

In Hungary the basis of the sport-system is the sports club; this did not change after the transition. In 1963 the first "children and youth" sports club was founded, where the imagined talentcare system (the official name of the system was Unified System of the Sport Talent Care - USSTC) started to emerge. The main part of the system was constituted by the sport-schools (Csanádi 1970).

Figure 1 shows the different parts of the USST. The "starting point" was the population of 618 year-olds; in 1970 more than 2.2 million children lived in Hungary. The vast majority of them learned in elementary or secondary schools. If the children were talented at sport, they attended the sports-school. Every 6-7 year-old child took part in a measuring-system, where they did different exercises.

The number of sport-schools was limited, but we should declare that the sport (P.E. lesson) was prescribed in the "simple" schools as well. Different sports-teams of the schools entered the competitions; they tried to defeat the sports-schools. The coaches and leaders of the sports-clubs tried to identify the talented children in these school-competitions, so the selection methods were good. The third part of the system was the sport-clubs, where qualified coaches were employed to deal with the children. Despite their excellent work the talented children from the sport-schools got into the regional national team. The regional sports federations organized sport-camps every year, in which the children who studied in general schools could take part. It happened that the leaders of the camps attracted the attention of the talented young, and these were called up to the regional national team. The sport clubs had always competed with each other, therefore the talented young were continuously kept in view.

The know-how of the sport school system was located at the join of the education and the sport spheres. The lectures in these schools were as important as in other schools, but the time-frame of the lectures was prescribed by the training sessions. For example, the first lesson began at 9 o'clock in the morning; therefore, the morning training could be held. 


\section{Central Sport School (CSS)}

In 1963 the Hungarian Physical Education and Sport Federation adopted a resolution which declared the foundation of the CSS. This centre was not just a sport school like the other schools: it was the centre of scientific life. Of course the most important aim of the school was to identify and nurture the talented young in the capital city. The most qualified coaches and researchers worked in the centre in that period. The coaches and the researchers collaborated closely. Five sports were launched in 1963, and the number of sports rapidly increased. The athletes of the CCS won national and international competitions. The coaches could adopt the latest results of the investigations; sometimes they started new research-projects as well. As the CCS was the citadel of the talent-care system, the results of the researchers were handed over to the other sport schools and sports clubs. Three main objectives were declared:

1). the CCS has to provide the financial backing of the following Olympics Team;

2). the CCS has to develop the newest talent-care model, which should be adopted around the country;

3) the CCS has to educate the future well-qualified coaches.

The Office for Sport-Methodological Research conducted physiological, psychological and sociological research; the results were wide-spread, not only in Hungary, but also in Europe. These results were well documented and the databases remain available today.

\section{Change in the situation at the end of the 1980s}

The above-listed objectives should have been reached by the middle of the 1980s. The talentcare system had to face several challenges. The most changing situation was the unfavourable demographic transformation. In 1970 the number of the 5-19 year-olds in Hungary was 2.4 million. The national census measured only 2.1 million for this age-bracket in 1980, the reduction was considerable and the trends were negative. The number of young people concerned was 1.8 million at the turn of the millennium, which reflects a $25 \%$ reduction. Figure 1 shows the results of the last five central national censuses.

In addition to the demographic issue, the political transition also influenced the backing of the field. The latest research results show that at the end of the 1980s:

- considerable structural and professional erosion started in Hungarian sport;

- the financial sources diminished drastically;

- interest in sport decreased among the youth;

- the system of the sport, especially that of youth sport, disintegrated.

\section{The situation around the millennium}

The sport-clubs and the sport schools were severely hit by the transition. Not only did they lose a huge percentage of their financial backing, the rules were changing as well. After the privatization of state-companies, the new ownership-strata did not sponsor the sports clubs. The regulations required the sport-schools to be transformed into "simple" schools or sports clubs. The situation was very uncertain, because the state gave a lot of money to sport clubs; the state's paternalistic political attitude remained prevalent. These "money-channels" opened randomly, the system was over-politicised. The sport clubs did not adapt to the different economic situation.

The clubs cut the money for youth sports, and the USSTC system collapsed. At the end of the 
1990s some national sports federations (soccer, track and field, basketball and handball) recognised that this situation could not be sustained. The position of these sports in Hungarian sport-life and the good connection with the government led to the beginning of some new sport-development programs. The central budget developed these talent-sport programs, receiving more than 10 million euros. The programs functioned with different structural systems; the output of these programs was not measurable. The sport state government (Ministry of Youth and Sport) realized this situation and founded a new funding institute. The name of the institute was National Institute for the Sport Talent Care, and the principal task of the institute was to work out and start up the new talent care system.

\section{National Institute for the Sport Talent Care (NISTC)}

The talent care strategy separated the 6-23 year-old athletes between 3 levels:

- The first level is the Sport XXI. Program, where the 6-14 year-olds are assembled;

- The second level is the Heracles Champion Program (HCP), for the 14-18 year-old age group;

- At the top of the system is the Heracles Star Program (HSP), for the 19-23 year-olds.

The decision-makers thought that the main erosion proceeded in the 14-18 age group, therefore the second level was immediately launched in 2001, whereas the first and third ones began in 2005. Let us see the characteristics of the different subsystems.

\section{Level 1 (Sport XXI. Program)}

Shaping the selection methods, and investigating the way of beginning sporting life in childhood, is the fundamental area of the talent-care system. The children are in the focus of the Sport XXI. Program. The aims of the program are to develop the system-background of sports (develop the sports-clubs, the coaches), persuade the children to go back to the track and field area or to the gym hall. Nowadays more than 600 sports clubs and schools get money from the Program, and these assistant organizations regularly hold training for the children, as well as organizing competitions.

Every year the NISTC collaborates closely with the national sport federations, assembling the list of the institutions to be developed. These organizations get a pre-determined amount of money for a year, therefore they have to pay the incidental expenses. In 2007 more than 60,000 children were registered in the program.

\section{Heracles Champion Program}

In sport, the amount of training and competitions considerably increases after childhood. The weekly training time of the sport-talented teenagers (after the age of 14) is in fact more than 25 hours. This is the most sensitive period of a teenager's life, and not only in the field of the sport. They have to study, they start to be interested in the other gender. The central aim of the HCP is that the selected talented young do not disappear and that they reach the international top level. These athletes are given equipment, the HCP pays for the training camps and the cost of the international competitions. All in all the HCP employs approximately 120 highly-qualified coaches.

The results of the HCP are the following:

More than 5,000 talented young athletes get in the scope (between 2001 and 2008);

The national sport federations work out the sport-specific talent-care system - but these strategies are in close connection with the NISTC system; 
The majority of the training will be held in the sport clubs in the future too, but the clubs work under professional control;

The talented athletes won more than 320 top 8 places in the European- and World Championships last year.

Heracles Star Program

We found that the successful athletes who exited the HCP system could not immediately enter the world of the elite top athletes; the percentage of dropout athletes was high. The HSP manages the athletes personally; the success of the program is indicated by the numerous results (for example, more than $40 \%$ of Hungarian athletes participating in the Beijing Olympics were in the HCP).

\section{The position of the CSS nowadays}

The CSS lost its sport-school status in 1996 and was divided into two independent organizations: one school and one sports club. The school is operating as a normal elementary and secondary school, atended by more than 1,000 children. The board of the school assists sport (for example the board organises extra lessons for the athletes who are absent from a lot of lessons due to their taking part in international sport competitions).

Although the CSS lost the central position of the talent-care system, 20\% of the athletes are in the Sport XXI, HCP or HSP. The office of the CSS is in the same building as the central office of the NISTC, and the director of the CSS also has a seat on the advisory board of the NISTC.

\section{Objectives of the research}

The social position of youth is defined by that of their parents; thus, when examining the social chances of junior athletes, the consideration of their parents is inevitable. The main objective of our research was to investigate the social background of young athletes. The present study focuses on social stratification in sports participation in a special population, that is, the young athletes. Furthermore, our aim was to examine whether the social differences revealed in a research work conducted on a similar population more than 30 years ago have changed, and if yes, to what extent.

In accordance with previous studies, the objectives set and the questions of the empirical research, the following research questions were set:

Is it true that, similarly to the results 30 years ago, young people in a more favourable financial and cultural situation stand a better chance of becoming an athlete than their less fortunate counterparts?

Is it true that, compared to the results of 30 years ago, there is a difference between the sports included in the present-day CSS regarding the social background of the children entering?

\section{Methods}

In order to answer the research questions, primarily the survey method was applied; nevertheless, to draw comprehensive conclusions, the analysis of documents and the conducting of indepth interviews were also necessary.

In the research we have to separate the involved populations. One subpopulation is the athletes who were registered in the CSS in 1976. As has been mentioned, the research office of the CSS carried 
out sociological research as well. Every first-grade athlete had to complete well-structured questionnaires; the total 1976 population is 660 . We found 551 completed questionnaires in the filing cabinet, which is more than $83 \%$ of the total population. We made a new database for the questionnaires and typed data; they constitute one sub-sample of our research.

The other subpopulation is the athletes who were registered in the CSS in 2008. The total 2008 population is 830 , the same questionnaires were distributed as in 1976 , the return-rate is $77.6 \%$. This is little bit less than 30 years ago but is acceptable in sociological research. We did not use any sampling method because we could reach almost all the athletes (we cooperated with the coaches). The gender proportion bends towards males in both of the samples $(74.7 \%$ male $-25.3 \%$ female in $1976 ; 71.2 \%$ male $-28.8 \%$ female in 2008). The sports are different in the examined period; Table 1 shows the list of the sports.

Table 1. The list of the examined sports - in 1976 and 2008

\begin{tabular}{clcc}
\hline Sports & $\mathbf{1 9 7 6}$ & $\mathbf{2 0 0 8}$ \\
\hline 1 & Table tennis & $\mathrm{X}$ & $\mathrm{X}$ \\
2 & Track and field & $\mathrm{X}$ & $\mathrm{X}$ \\
3 & Judo & $\mathrm{X}$ & $\mathrm{X}$ \\
4 & Kayak-canoe & $\mathrm{X}$ & $\mathrm{X}$ \\
5 & Bycicle & $\mathrm{X}$ & \\
6 & Basketball & $\mathrm{X}$ & \\
7 & Soccer & $\mathrm{X}$ & $\mathrm{X}$ \\
8 & Boxing & $\mathrm{X}$ & $\mathrm{X}$ \\
9 & Modern pethathlon & $\mathrm{X}$ & $\mathrm{X}$ \\
10 & Sportlövészet & $\mathrm{X}$ & $\mathrm{X}$ \\
11 & Tennis & $\mathrm{X}$ & \\
12 & Gymnaastics & $\mathrm{X}$ & $\mathrm{X}$ \\
13 & Fencing & & \\
14 & Water-polo &
\end{tabular}

We used SPSS 15.0 program for data analysis, the applied statistical methods are mentioned in the subsequent part of the paper.

\section{Results and discussion}

In the section below, we present the results of our study in the following aspects: knowledge, qualification, income, property wealth, ownership of durable goods.

\section{Knowledge}

In the past 30 years, similarly to other European countries, the average number of years spent in education has increased in Hungary; at the beginning of the 1990s, the colleges and universities opened their doors to a wider population. The first aspect of our research was to measure the educational levels of the parents. We compared the results of our study with the Central Statistical Office (KSH) data, which can be accepted as relevant for the entire Hungarian population. First of all, it is clear that over the last three decades socio-educational status as well as socio-professional status has increased in Hungary.

The result show that nowadays nearly all parents finished elementary school. The expansion of the educational system is apparent. We compared the data of 1976 and 2008, and we found statistical differences. The number of those having finished only elementary school has reduced, and the number 
of those having finished college or university has increased. We tested our assumption with the Person Chi-Square test $(\chi 2$ value $=120.681 ; \mathrm{df}=15 ; \mathrm{p}<0.01)$, the result shows that the differences are not accidental.

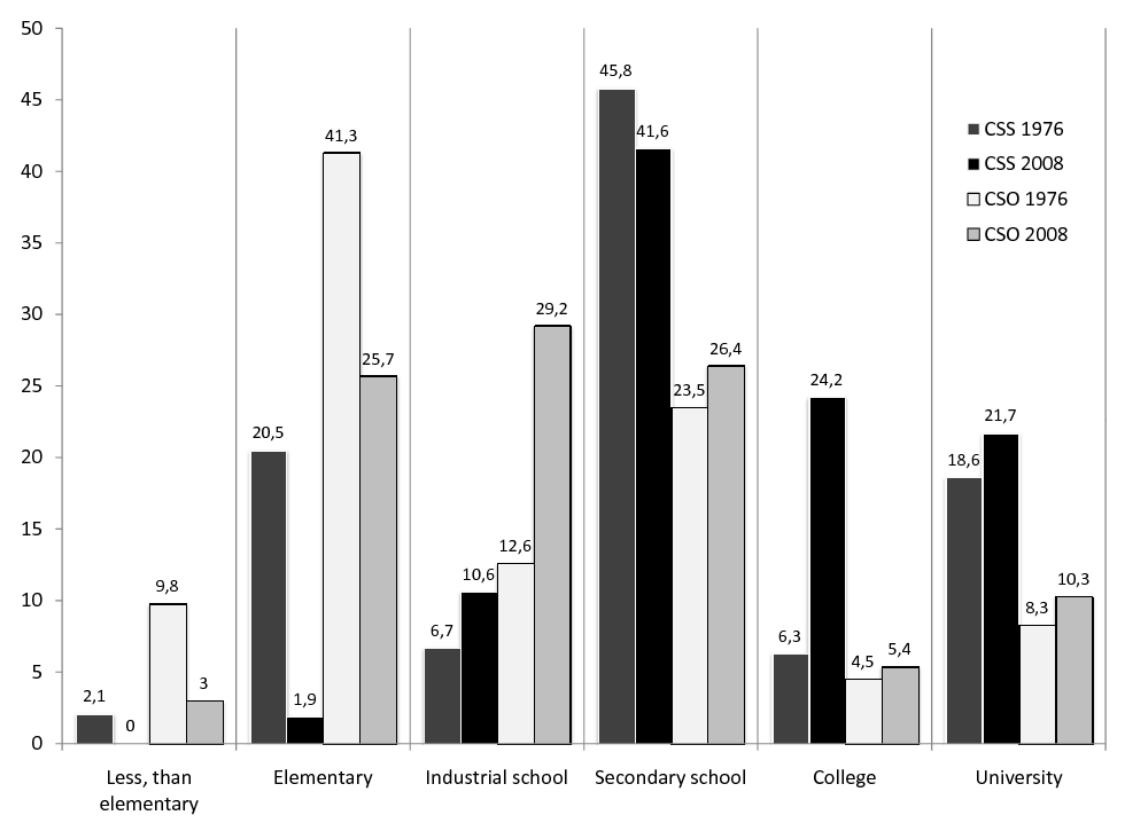

Figure 1. The educational levels in the subpopulations (\%).

Qualification

Similarly to educational status, the qualification status has also changed in Hungary. Figure 2 shows that the percentage of white-collar workers in the overall population has increased. In the 1976 CSS sub-sample's distribution of the white - blue collar workers was $57 \%$ to $43 \%$, so the white collar workers were over-represented in the sample.

The white - blue collar worker proportion in the 2008 CSS subpopulation is $83.2 \%$ to $16.8 \%$, which is much more different than the country's average. The results of the Person Chi-Square test is the following: $\chi^{2}$ value $=57.715 ; \mathrm{df}=3 ; \mathrm{p}<0.01$ ). 


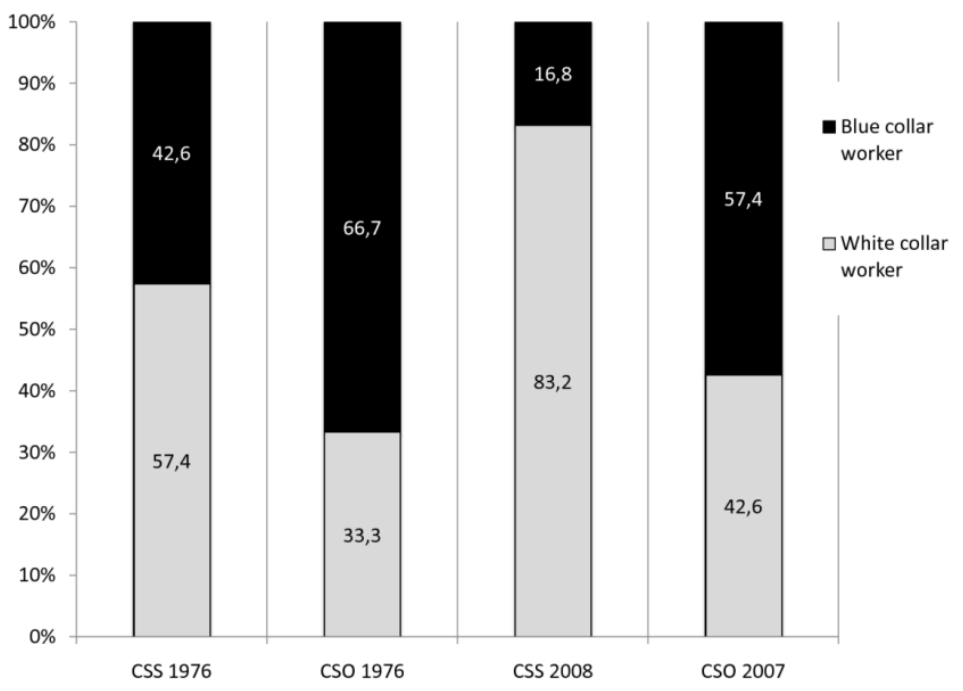

Figure 2. The distribution of white and blue collar workers in the subpopulation.

Income

The most difficult aspect of analysis is the changing of the income situation over the last three decades between the CSS's parents. In this respect, we modified the questionnaire; in 1976 the parents wrote the income in the original questionnaire, however, we supposed that nowadays these kinds of question result in a lot of missing values, and we therefore asked the parents to chose one category from the list. The fact that white collar workers earn more than the blue collar ones has been identified in the samples as well. The athletes' parents earn more money than the average.

Table 2. The average net income in the different sub-samples - in 1976 and 2008.

\begin{tabular}{llll}
\hline & & Blue collar worker & White collar worker \\
$\begin{array}{l}\text { Average net income } \\
\text { (1976) }\end{array}$ & CSS & $3.320 \mathrm{HUF}$ & $4.136 \mathrm{HUF}$ \\
\hline & $\mathrm{CSO}$ & $2.277 \mathrm{HUF}$ & $2.801 \mathrm{HUF}$ \\
\hline \multirow{2}{*}{$\begin{array}{l}\text { Average net income } \\
(2008)\end{array}$} & CSS & $80-110.000 \mathrm{HUF}$ & $131-180.000 \mathrm{HUF}$ \\
& & $270-340 \mathrm{EUR}$ & $440-600 \mathrm{EUR}$ \\
& $\mathrm{CSO}$ & $78.000 \mathrm{HUF}$ & $131.000 \mathrm{HUF}$ \\
& $265 \mathrm{EUR}$ & $440 \mathrm{EUR}$ \\
\hline
\end{tabular}

Property wealth

Individual property wealth was restricted in the socialist states. The state decided who got a flat, the real estate market was limited in the capital city, and therefore, the accumulated capital is not reflected in this aspect.

In the last 30 years the situation basically changed, also with regard to life-styles and the regulative circumstances. The average size of a flat for one person was $18 \mathrm{~m}^{2}$ in 1976: this increased to $25 \mathrm{~m}^{2}$ for 2008. We asked about the size of the house/flat, and the result was very surprising: the average size of the flat/house is approximately $100 \mathrm{~m}^{2}$. The CSS functions in the $14^{\text {th }}$ district of Budapest, which is very fashionable among the middle-classes. A large part of the talented young athletes live in this district. The parents also estimated the value of their flat/house (see Figure 3.). 


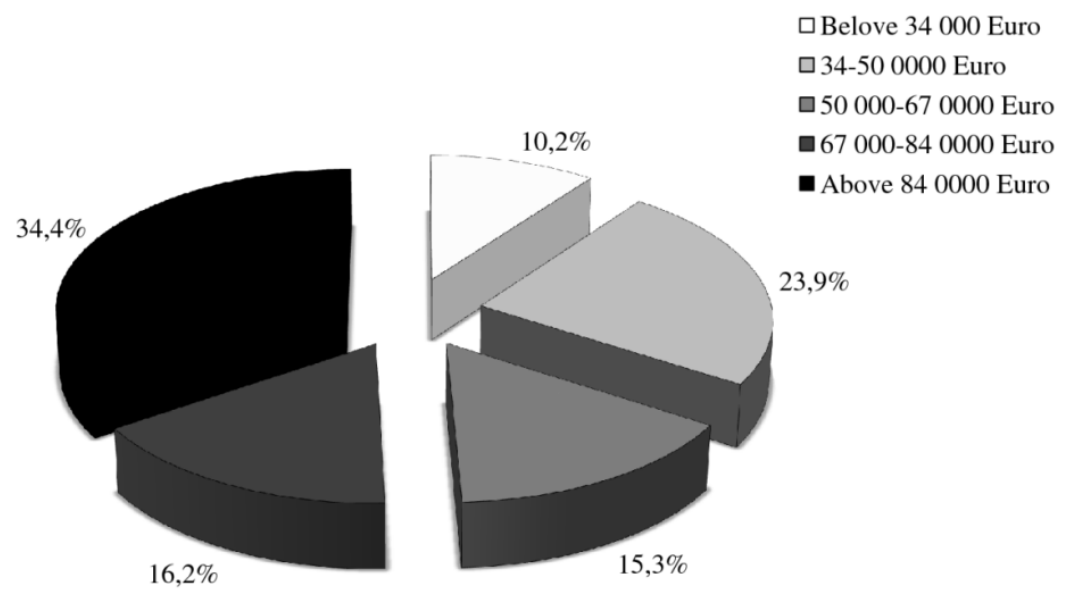

Figure 3. The value of the flat/house in the CSS 2008 sub-sample

Ownership of durable goods

Measuring the ownership of durable goods is a widely accepted indicator in sociological research, with stratification investigations. The change of lifestyle allowed people to purchase different consumer goods - especially those which made their lives easier. The most widespread durable good is the automobile. The share of the car-owners in the capital city was $8.35 \%$ in 1976, and compared to this $10.3 \%$ of the CSS's parents had a car. In 2008, more than $82 \%$ of the CSS's parents had a car, in this respect the overall national average is $50 \%$.

Almost every family has a personal computer, but we could not compare this data with the data from three decades ago. The average computer prevalence is $66 \%$ in Budapest (the average for the country is $33 \%$ ). $72 \%$ of families possess broadband internet, in this case the most striking deviation from the average (15\%) can be observed.

\section{Differences among the sports}

During the process of the secondary analysis, we did not find any differences among the parents' social status - in the dimension of the sports. We assumed that we could find variance between the different sports; therefore, we calculated a complex socioeconomic variable (we involved the educational level, the net income, the ownership of a car, the size of the flat/house and the value of the house). We found some "elite sports" (water-polo, pentathlon) in which the parents are in the narrow elite class. These parents have financial and intellectual capital too. We classified the parents whose children participate in track and field or shooting events in the other group. These parents have the intellectual capital (they have a degree) but they possess less financial capital. For example, teachers can be put into this group. We could describe the third group as the less affluent group; they have less intellectual and financial capital than the other group. Boxing and gymnastics are in this group.

\section{Conclusion}

It is widely believed that the door of sport is open to everyone. Nowadays, more than ever before, the costs of sport are high, parents have to pay the membership fee, they have to buy the newest equipment, fund the training camps etc. This means that sport participation is closely 
connected with who has what in society.

In our paper we analysed the social background of the children participating in the national talent-care program and compared the results with research from three decades earlier. The results show that the parents are in a good position - the trend did not change. Unfortunately, social inequalities can be identified in sport, and the socially disadvantaged children are squeezed out of the field. Everyday training and the preparation for school demand that the family needs to give considerable assistance to the children. If the background is unfavourable, then the children do not get into the sports club.

\section{REFERENCES}

A budapesti összehasonlító elemzésekhez a Szonda Ipsos 2004-es reprezentatív sportfelméréséből azokat a személyeket válogattam ki, akik budapesti lakosok és életkoruk 37 és 44 év között van. (ebbe a korosztályba tartozik a KSI-s szülők több mint fele)

Földesiné, Sz. Gy. (1992). Sport for All and New Political Reality in the Eastern European Countries: What will the future bring? In Roland Bassler (Eds.) Gessellschaftliche Veränderungen und ihre Auswirkungen auf den Sport. Wien: WUV Universitätsverlag, pp. 97-103.

Földesiné, Sz. Gy. (1996a). Sports Policy in Hungary. In Chalip, L., Johnson, A., Stachura, L. (Eds.) National Sports Policies. International Handbook. Connecticut-London: Grenwood Press, Westport, pp. 187-221.

Földesiné, Sz. Gy. (1996b). Sport and Policy for the Disabled. In Kalokagathia. 1-2. sz., pp. 84-89.

Földesiné, Sz. Gy. (2000). Retirement of top athletes in a changing society. In Kalokagathia. 75th Anniversary Special Issue, pp. 12-23.

Gazsó, F., Laki, L. (1993). Esélyek és orientációk. Fiatalok az ezredfordulón. Budapest: OKKER Kiadó.

Mozaik 2001: magyar fiatalok a Kárpát-medencében. (2002). Nemzeti Ifjúságkutató Intézet. Budapest.

Statisztikai évkönyv (1976). 309. o.

Szapu, M. (2001). A zürkorszak gyermeke: mai ifjúsági csoportkultúrák. Budapest: Századvég.

Területi statisztikai évkönyv (1976). 196. o.

1980-as adatok: 1980. évi népszámlálás I. KSH 1981. 8-9. o.

2001-es népszámlálási adatok a: http://www.nepszamlalas.hu/hun/egyeb/eurostat/tables/tabhun/load1_10.html weboldalról, a 35-39 éves korosztályban.

http://gender.bkae.hu/konf2003/szucszoltan.pdf

http://portal.ksh.hu/pls/portal/ksh_web.tdb.view_cath?lang=HU\&parent=4231

http://portal.ksh.hu/portal/page?_pageid=37,112477\&_dad=portal\&_schema=PORTAL

http://www.jadat.hu/Mp010206.pdf

http://www.nepszamlalas.hu/hun/egyeb/eurostat/tables/tabhun/load1_11.html

http://www.tarki.hu/adatbank-h/kutjel/pdf/a745.pdf

http://www.xpedient.hu/hirek/A-magyar-haztartasok-es-az-Internet/ 